Asfahani khaled (Orcid ID: 0000-0003-0718-4386)

Krokos George (Orcid ID: 0000-0001-7428-0066)

Papadopoulos Vassilis, P. (Orcid ID: 0000-0001-5877-5149)

Jones Burton, H. (Orcid ID: 0000-0002-9599-1593)

Kheireddine Malika (Orcid ID: 0000-0002-2726-5426)

Hoteit Ibrahim (Orcid ID: 0000-0002-3751-4393)

\title{
Capturing a Mode of Intermediate Water Formation in the Red Sea
}

Khaled Asfahani ${ }^{1,2}$, George Krokos ${ }^{3}$, Vassilis P. Papadopoulos ${ }^{4}$, Burton H. Jones ${ }^{1}$, Sarantis Sofianos ${ }^{5}$, Malika Kheireddine ${ }^{1}$ and Ibrahim Hoteit $^{3}$

${ }^{1}$ Biological and Environmental. Science and Engineering Division, King Abdullah University of Science and Technology (KAUST), Thuwal, Saudi Arabia

${ }^{2}$ Environmental Protection Department, Saudi Aramco, Damam, Saudi Arabia

${ }^{3}$ Physical Science and Engineering Division, King Abdullah University of Science and Technology (KAUST), Thuwal, Saudi Arabia

${ }^{4}$ Hellenic Centre for Marine Research (HCMR), Anavissos, Greece

${ }^{5}$ Division of Environmental Physics, National and Kapodistrian University of Athens (UOA), Athens, Greece

Corresponding author: Khaled Asfahani (khaled.asfahani@kaust.edu.sa)

This article has been accepted for publication and undergone full peer review but has not been through the copyediting, typesetting, pagination and proofreading process which may lead to differences between this version and the Version of Record. Please cite this article as doi: 10.1029/2019JC015803 


\title{
Key Points:
}

- First glider observations were collected over the northern Red Sea during winter of 2016 reveal a mechanism of intermediate water formation

- The convection process depends on the persistence of strong atmospheric forcing and the activation of a semi-permanent cyclonic gyre

- Transition from scattered eddies to a cyclonic gyre, deep mixing and advent of water from the south are the key features of water formation

\begin{abstract}
Formation of intermediate waters in the northern Red Sea was captured by Seagliders during the winter of 2016. The analysis is based on measurements collected by consequent deployments of Seaglider AUVs along a $70 \mathrm{~km}$ transect, which was run repeatedly from the coast to mid-basin during the period from October 2015 to May 2016. The observations revealed typical open ocean convection processes including a preconditioning phase followed by deep convection and spreading of the newly formed waters through lateral exchange. Winter conditions were characterized by surface cooling and enhanced evaporation, which were observed from late October until late February. During this period, the gradual surface cooling and salinity increase resulted in the weakening of the surface stratification. Recurrent cyclonic gyres forced by strong atmospheric events led to episodic convection and the formation of intermediate sea water typical of the upper overturning circulation cell of the Red Sea. Following deep mixing, a remarkable bloom of chlorophyll was detected at the top layer of the water column in response to the nutrients delivery from the deeper layers. The end of winter was marked by the intrusion of lower salinity water presumably advected from the south and the reestablishment of the general cyclonic circulation, typical for the northernmost part of the Red Sea. To the best of our knowledge, this is the first observation study of such convection events in the northern Red Sea.
\end{abstract}

\section{Plain Language Summary}

Water formation in the northern Red Sea during winter plays an important role in the basin's overturning circulation. Dense hypersaline water formed in the northern parts of the basin travels at intermediate depths towards the south and finally exits into the Indian Ocean. We describe for the first time a mechanism for the intermediate water formation, which was 
deduced from Seaglider records captured during the winter of 2016. We present the response of the upper sea water column to episodic atmospheric forcing events and the crucial role of cyclonic gyres in the convection process. During the period of observations, several events with simultaneous activation of the cyclonic gyre favored the winter surface cooling and led to open ocean convection. Vertical mixing in the water column supplied the near surface layer with nutrients, which caused a remarkable chlorophyll bloom. The deep mixing events occurred over very short periods, typically less than a week, and were followed by rapid restratification of the surface layer.

\section{Introduction}

The North Red Sea (NRS) is an area of great significance for the whole basin ventilation. As the elongated Red Sea spans almost 20 degrees of latitude (Figure 1), its northern part, located between $26^{\circ}$ and $30^{\circ} \mathrm{N}$, is dominated by a typical subtropic seasonal climatic cycle. Similar to the neighboring Mediterranean, the elongated Red Sea undergoes water renewal with the Indian Ocean via an upper layer cell of overturning circulation. During winter, high rates of evaporation and significant cooling of the surface sea water occurring regularly in the NRS produce the bulk of basin's intermediate water (Cember, 1988; Sofianos \& Johns, 2003; Yao et al., 2014; Papadopoulos et al., 2015; Zhai et al., 2015; Osipov \& Stenchikov, 2017; Menezes et al., 2019). This intermediate water is the well known Red Sea Outflow Water (RSOW) that flows to the far south and finally exits to the Gulf of Aden as a remarkable injection of hypersaline water to the Indian Ocean (Sofianos et al., 2002; Sofianos and Johns, 2003; Yao, et al., 2014a,b; Zhai et al., 2015). In addition to this upper layer cell, a deep cell is also sustained by the winter thermohaline circulation and the formation of the Red Sea Deep Water (RSDW; Yao \& Hoteit, 2018). The RSDW occupies the deeper layers while the RSOW is confined within the first $400 \mathrm{~m}$, and it is distinguished from the underneath RSDW by its higher concentration in dissolved oxygen (Woelk \& Quadfasel, 1996; Sofianos \& Johns, 2007; Papadopoulos et al., 2015).

Convection processes are localized in both space and time, and therefore, few historical observations have captured such events (Marshall \& Schott, 1999). Alongside the known convection sites in the polar regions, open ocean convection can also take place in midlatitude regions such as the Sea of Japan (Kim et al., 2008) and in various sites in the Mediterranean Sea, such as the Gulf of Lions, Adriatic Sea, and Aegean Sea (Sparnocchia et al., 1995; 
Malanotte-Rizzoli et al., 2014). Defined by a topography of closed geographic contours and forced by intense winter atmospheric fluxes, the Red Sea includes all of the important features for the establishment of convection processes. Similar to other sites typical of convection events, the Red Sea undergoes buoyancy-forced thermohaline circulation. Warm and relatively fresh water of Indian Ocean origin travels northward through a complex near surface circulation, exposed to the atmospheric forcing and becomes much saltier and relatively colder (Sofianos \& Johns, 2015). Over the northernmost part of the Red Sea, this water becomes dense enough to sink and then follows an opposite route back to the Indian Ocean, thus completing an upper layer overturning cell. Given its relatively small size, the Red Sea provides an ideal test basin to study the dynamics of water formation processes and its effects on the general circulation.

The RSOW is the dominant water mass occupying the intermediate depths below the pycnocline, typically between 150-250 m, throughout the Red Sea (Eshel et al., 1994; Sofianos and Johns, 2015; Yao, et al., 2014). Formation of the RSOW is suggested to regularly take place in the northernmost part of the basin during winter by means of both nearshore shelf convection and open ocean convection. The latter is occasionally subserved by the regional characteristics of the upper layer circulation. Numerical simulations and observations suggest that less saline and relatively warmer water arrives at the northern edge of the Red Sea mainly through an Eastern Boundary Current that flows intermittently along the Saudi coastline (Bower \& Farrar, 2015; Sofianos and Johns, 2003; Yao et al., 2014b). This surface boundary current contributes to a broader cyclonic circulation in the NRS, which is episodically intensified into a semi-permanent cyclonic eddy in response to strong atmospheric forcing that prevails mainly during winter (Papadopoulos et al., 2015; Sofianos \& Johns, 2003, 2007; Zhan et al., 2014). Cyclonic eddies in the NRS can be mostly attributed to buoyancy fluxes, whereas wind stress seems to play a secondary role (Zhan et al., 2016, 2018). Intensification of this cyclonic eddy promotes convection events by uplifting denser waters from deeper layers and weakening the surface pycnocline (Sofianos and Johns, 2003). Synergy of the local circulation and atmospheric forcing potentially leads to open ocean convection and formation of RSOW (Papadopoulos et al., 2015).

This is the first study to analyze glider observations over the NRS capturing the dynamics of the winter convection processes that lead to intermediate water formation. This water fuels the pivotal upper cell of the basin's overturning circulation. The atmospheric forcing and the role of the regional circulation in the RSOW formation are described and 
analyzed. The article is organized as follows. Section 2 describes the data and methods, Section 3 discusses the atmospheric forcing and the response of the NRS to intense cooling events, and Section 4 summarizes the main findings of the study.

\section{Datasets and Methods}

\subsection{Observations - Seaglider Sampling}

Seagliders were deployed in the NRS from late September 2015 through mid-May 2016, and they were programmed to travel following a transect approximately $70 \mathrm{~km}$ in length (Figure 1). The nearshore edge of the transect line was about $5 \mathrm{~km}$ offshore from the Saudi coastline, whereas the offshore edge was close to the mid-axis of the Red Sea. On average, the gliders required about 3 days to complete the $70 \mathrm{~km}$ trek along each transect. Data from both downcasts and upcasts were used in our analysis. Details of the seaglider missions are presented in Table 1 .

The Seagliders used during this study took measurements of the temperature, pressure, conductivity, dissolved oxygen and chlorophyll-a (Chl-a) fluorescence. An Iridium satellite was used to transmit the data from the Seaglider to the workstation on land at the end of each dive cycle. Temperature and salinity were determined using a Seabird CT sensor, while dissolved oxygen concentrations were determined using an Aanderaa optode sensor. Raw instrument measurements (counts) for each parameter were transformed into geophysical quantities by applying the manufacturer-provided scaling factor and dark count. Then, each profile was quality-controlled applying methods that have been specifically developed for each parameter (Organelli, 2017; Schmechtig et al., 2016; Thierry et al., 2011 and references therein) following Argo's 'real-time' quality control procedure and data management (Wong et al., 2018). Briefly, following Schmechtig et al., (2016), vertical profiles of Chl-a were adjusted for non-zero deep values, and corrected for non-photochemical quenching according to Xing et al. (2012). Furthermore, the Chl-a values were then divided by a factor of 2 to correct the overestimation observed by standard Wet Labs fluorometers as described in Roesler et al., (2017). Spikes were removed from the Chl-a measurements using a low-pass median filter. Corrections of $\mathrm{O} 2$ measurements were performed by applying a factor (1.06 to 1.23 according to the glider mission and seasons) to each profile based on the comparison between the surface percent oxygen saturation values and those from the World Ocean Atlas climatology, as described by Takeshita et al. (2017). Finally, Temperature, salinity, Chl-a and O2 qualitycontrolled vertical profiles were binned in $2 \mathrm{~m}$ intervals and interpolated onto a grid with 2.5 
$\mathrm{km}$ horizontal spacing. The mixed layer depth (MLD) was defined through a fixed density threshold method with a finite difference criterion from a reference depth, typically set at $10 \mathrm{~m}$ to avoid diurnal cycle variations (de Boyer Montégut et al., 2004). The criterion in density is set to $0.0125 \mathrm{~kg} / \mathrm{m} 3$ difference from the reference depth. Geostrophic velocity is referenced to a level of no motion at $450 \mathrm{~m}$ suggested by the minimum dissolved oxygen concentration as derived by the respective profiles (see Figure 4).

\subsection{Model Data - Atmospheric Forcing}

Daily surface wind and heat fluxes (sensible, latent, and humidity) were obtained from a downscaled, high resolution reanalysis product derived with an assimilative Advanced Weather Research and Forecasting (WRF) atmospheric model (Viswanadhapalli et al., 2016). These data have been generated for the period of 1990-2016. The model was designed with two-way interactive nested domains of 30 and $10 \mathrm{~km}$ horizontal resolutions and 35 vertical levels. The inner domain $(5 \mathrm{~km})$ covers the Red Sea and adjacent regions. The initial and boundary conditions were obtained from the European Center for Medium-Range Weather Forecasts (ECMWF) reanalysis. All available observations in the region were assimilated (every $6 \mathrm{~h}$ ) by using a consecutive integration approach. Assimilated data included conventional observations from the surface (synoptic stations, METARs, ships, and buoys), upper-air observations (radiosondes and pilot balloons), and satellite observations. The simulated variables were extensively validated with all available observations at different time scales. Of particular interest for this study is the significant improvement of the high-resolution fields in the descriptions of wind dynamics, especially in the NRS. Further details on the experimental design and methodology as well as the comparative advantages of such a regional analysis compared to other global products are provided by Viswanadhapalli et al. (2016). The regional reanalysis has been also used and validated in various studies and applications (Dasari et al., 2017, 2019; Langodan et al., 2014, 2015, 2016, 2017; Viswanadhapalli et al., 2016; Zhan et al., 2016).

\subsection{Remotely Sensed Data}

The evolution and variability of the sea surface temperature (SST) in the Red Sea was investigated by using the operational Global Foundation Sea Surface Temperature Analysis (G1SST) product from the National Aeronautics and Space Administration's (NASA) Jet Propulsion Laboratory Our Ocean group (Chao et al., 2009).This dataset provides daily SST fields on a 0.009 degrees horizontal resolution spanning the period 2010 to present. G1SST is 
based on a blend of satellite data from microwave and infrared satellite instruments distributed via the Group for High Resolution SST (GHRSST) mixed with in situ data from drifting and moored buoys. The high spatial resolution of this product allows analyses of fine scale structures and provides a better representation near coastal regions, both essential for this study. The G1SST dataset was retrieved through the NASA EOSDIS (Earth Observing System Data and Information System) Physical Oceanography Distributed Active Archive Center (PO.DAAC) at the Jet Propulsion Laboratory, Pasadena, CA at http://dx.doi.org/10.5067/GHG1S-4FP01.

\section{Results and Discussion}

\subsection{Atmospheric Forcing}

Air temperature, specific humidity, wind, and net air-sea heat exchange averaged between 26$28^{\circ} \mathrm{N}$ for the period spanned by the glider deployments (October 2015-May 2016) are shown in Figure 2. The air temperature followed the typical seasonal evolution from high values near $28^{\circ} \mathrm{C}$ during October to values around $18^{\circ} \mathrm{C}$ during winter, before it rose again after the end of January. Several cold outbreaks were observed from early December to 10 February (Figure 2a), during which the air temperature was episodically reduced to less than $16^{\circ} \mathrm{C}$. These cold events were accompanied by drier air (Figure 2b), typical for the region during strong northnorthwest wind (Figure 2c). Accordingly, sudden plunges of the net air-sea heat exchange led to abnormal, excessive heat losses at the sea surface (Figure 2d). Intrusion of cold, dry winds blowing from higher latitudes over the broader region is typical for the winter and is associated with patterns of favorable large-scale atmospheric circulation (Papadopoulos et al., 2013; Viswanadhapalli et al., 2016). The net heat flux exhibited high variability throughout the glider deployments period, characterized by sudden drops after short periods of low variation. Values close to $0 \mathrm{~W} / \mathrm{m}^{2}$ prevail during October giving place to steady heat loss from November until March, with minima of about $-400 \mathrm{~W} / \mathrm{m}^{2}$ during December and January typical for the NRS (Abualnaja et al., 2015). Cold outbreaks were marked by the sudden drops in the net heat flux with values lower than $-500 \mathrm{~W} / \mathrm{m}^{2}$ during December and January. Expectedly, strong heat loss leads to surface cooling and favors convection in the sea water column.

\subsection{Nearshore-Offshore Water Characteristics}

This section presents the temporal evolution of the water column characteristics in the open NRS at the westernmost (offshore) and easternmost (nearshore) edge of the glider tracks (red 
and green marks in Figure 1). These two locations were selected to depict the dissimilar response of the offshore and nearshore waters to the winter forcing with respect to the regional circulation. The temporal evolution of the offshore temperature, salinity, and chlorophyll along with sea water density are presented in the left panels of Figure 3 (a, c, e). The water column was still well stratified in early October (Figure 3a), with surface temperatures exceeding $31^{\circ} \mathrm{C}$. Under steady heat loss, the surface layer progressively cooled until mid-February, and the remnants of the summer-induced stratification were disrupted. As the near surface water became much denser, a convection process formed gradually a nearly homogenized column in the first $300 \mathrm{~m}$ until late February-early March. The surface heat gain which started by mid February warmed the top of the water column and re-established the upper layer stratification. However, transitions from a well-stratified to well-mixed water column were observed over short periods, first at the end of December and second at the middle of February, when vertical mixing was much stronger and more persistent through time.

At the same time, the surface salinity exhibited high variability with patches of less saline surface water intermittently affecting the upper layers, revealing a regionally complex circulation (Figure 3b). Given the general gradient of salinity in the Red Sea, increasing towards the north, these fresher water masses are considered to be advected from the south. During the cooling events, the characteristic upward tilt of the isohalines indicates that salinity was homogenized in the upper $300 \mathrm{~m}$ by mixing with deeper layers, further contributing to the increase of density. By the end of April, stratification was intensified by heat gain and further advection of less saline water $(<40)$ in the upper $20-30 \mathrm{~m}$ of the water column was observed. In general, salinity exhibited higher temporal variability compared to the regular seasonal fluctuation of the water temperature, and it was strongly dependent on the variability of the regional circulation that led to the occasional arrival of less saline water from the south.

The chlorophyll concentrations of the upper layer also exhibited remarkable temporal variations (Figure 3c). At the early stages of the studied period, chlorophyll maxima were steadily trapped beneath the thermocline at the deep chlorophyll maximum (DCM). In early January, as stratification weakened, chlorophyll became dispersed within the upper 160-180m of the water column. Earlier studies in the region have revealed a strong relationship between phytoplankton abundance and convective mixing, through transport of nutrients from deeper layers (Genin et al., 1995; Gittings et al., 2018, 2019). As mixing intensified, nutrient-rich water reached the surface from the deep layers, consequently resulting in a peak of chlorophyll within the upper layer. Waning of the cyclonic gyre and rapid restratification resulted in the 
dissipation of chlorophyll in the upper layer as the upward nutrient flux has ceased and the newly formed waters have been laterally dispersed. The deep chlorophyll maxima were then found again beneath the re-established seasonal thermocline.

The evolution of the nearshore temperature, salinity, chlorophyll, and density is shown in the right panels of Figure 3 (b, d, f). Temperature (Figure $3 b$ ) exhibited a similar pattern to the offshore seasonal fluctuation, as the initial stratification of the upper layer gradually receded to a well-mixed water column of more than $150 \mathrm{~m}$ by mid-February. Salinity was consistent with temperature and also showed homogeneity to below $150 \mathrm{~m}$. Similarly, chlorophyll was initially confined at the DCM, and following mixing after the middle of December, it became dispersed within the upper 150m of the water column. By late February, the chlorophyll maximum is found again around the DCM. By the end of April, surface warming and probable advection of warmer, fresher water from the south reestablished the seasonal thermocline.

Nearshore salinity within the upper layer (0-150m) was always lower than the offshore counterpart at the same depths (Figure 3c, 3d). This fact is indicative of intermittent transport from the eastern boundary of warmer, less saline water northward along the Saudi coastline. The absence of obvious uplifts in the isotherms nearshore (the $22^{\circ} \mathrm{Cisotherm}$ was deeper than $250 \mathrm{~m}$ ) and the deeper mixed layer indicates that the newly formed water masses were spread in the periphery of the initial formation site. This was also supported by the lower chlorophyll concentrations observed near the Saudi coastline in comparison to the much higher offshore chlorophyll, which followed the mixing induced by the second cooling event (Figure 3e, 3f). The delay of the appearance of rich nutrient waters in the onshore profiles and its overall characteristics suggest lateral spread from the central NRS towards the shallower periphery, as denser water sunk beneath the less dense coastal water.

Evolution of the water column characteristics between October 2015 and May 2016 and the formation of new water were well illustrated in the successive offshore and nearshore profiles of temperature, salinity and oxygen (Figure 4). Both offshore and nearshore temperatures started from well stratified profiles on 28 September. Progressive surface cooling then led to mixed layer deepening that reached its maximum depth in early to mid-February. Stratification of the surface layer began again following the mid-February deep mixing, and it strengthened steadily until April. As the surface layer temperature increased, the salinity decreased from its winter maximum by almost 1 unit between 15 February and 26 April, most probably after the arrival of less saline water advected from the south in the NRS. Similarly, 
oxygen profiles in the offshore reveal a gradual bottom-up reduction, indicating the influence of the uplift of the isopycnals, which brings nutrient rich and oxygen poor waters closer to the surface. Nearshore profiles show a gradual increase in dissolved oxygen at the intermediate layers of the water column, perceptible to deeper than $300 \mathrm{~m}$ after February. Again, as this is evident only nearshore, it is well complied with the lateral spreading of the newly formed water (Figure 4). In contrast, no evidence of oxygen enrichment is detected at the offshore point as a result of the uplift of oxygen poor water around the central parts of the NRS.

The T-S diagram of Figure 5 depicts the evolution of the water mass characteristics at the nearshore and offshore end points of the glider tracks at selected time shots. During the first days of October both points were still characterized by warm surface water and stratified water column. By the end of December and after the first intensification of the cyclonic eddy, a drop in temperature and a rise in salinity, mainly at the offshore point, are observed. Further decrease of temperature and increase of salinity are evident after the second appearance of the eddy by the mid of February. At that time, the water physical characteristics are the least dispersed, especially offshore where the density is confined to values greater than 28.25 as a result of dense water formation and homogenization of the water column. It has to be noted that during both appearances of the cyclonic eddy, the offshore water is clearly more affected by the stronger vertical mixing close to the core of the eddy. In late April, warm and less saline water occupies again the near surface layer, especially nearshore, and the water column becomes again well stratified. Overall, the T-S diagram indicates the similarity of the subsurface water mass between the two points and the dissimilarities of the upper layer when the cyclonic eddy is active.

\subsection{Role of the Cyclonic Gyre Activity}

To analyze the impact of the cyclonic gyre on the dense water formation in the NRS, we present the glider transect data during the two periods when the cyclonic gyre was strengthened in the NRS. During the winter of 2015-2016, glider observations showed repeatedly that intensification of a cyclonic eddy took place immediately after strong heat loss events. An episode of strong cooling at the end of December coincided with the first appearance of the cyclonic eddy in the study area. Figure 6 illustrates the evolution of the vertical distributions of temperature (top panels) and salinity (mid panels) along the glider track, and the SST variability (bottom panels) over the NRS during the eddy intensification, spanning the period between 24 December 2015 and 14 January 2016. The period between 24 and 28 December, 
just few days prior to the first eddy appearance, was characterized by micro-domes of the isotherms, which were suggestive of complex circulation comprising small cyclonic and anticyclonic eddies within the upper $100 \mathrm{~m}$ of the water column. The isotherms presented a slight downward tilt toward the Saudi coastline, indicating a general cyclonic circulation pattern also depicted by geostrophic velocities (not shown). At the same time, the MLD is found just above and almost parallel to the isopycnal of 27.75. Between 28 December and 2 January, water colder than $23.5^{\circ} \mathrm{C}$ was detected at the surface in the central NRS, which was suggestive of the establishment of a cyclonic eddy that influenced at least the upper $300 \mathrm{~m}$ of the water column. MLD penetrated the isopycnal of 28 near the center of the eddy, but remained above the one of 27.75 for the rest of the transect. Between 10 and 15 January, recession of the eddy took place again according to small fluctuations in the thermocline, and data suggested the reinstatement of smaller and weaker eddies and complex circulation that transported less saline water to the nearshore part of the transect. This is also depicted in the MLD that has moved deeper and is now found just below the 27.75 isopycnal for the most of the transect, indicating a lateral transport of mixed waters towards the periphery. At the nearshore part, a less saline water intrusion rises the MLD to shallower depth well above the 27.75 . The cooling effect on the broader NRS induced by this first event, as well as the northward advection of warmer waters at the eastern boundary are also depicted by the SST satellite images (Figure 6, lower panels). Although this event was incapable of producing a deep mixed surface layer, its contribution was important to precondition the region for the next stirring phase of the water column.

Two more episodes of enhanced heat loss at the sea surface were observed during the last days of January and the first days of February (Figure 2d), just prior to the second stronger and more persistent appearance of the cyclonic gyre. Figure 7 shows the evolution of this second pivotal occurrence of the cyclonic gyre spanning a period between 3 and 23 February. For the same period, Brunt-Vaisala frequency (buoyancy frequency) and the geostrophic velocity are illustrated in Figure 8. Similar to the first episode, the period before the gyre activation was characterized by small cyclonic and anticyclonic eddies. A well stratified surface layer occupied the top of the water column and deepened towards the Saudi coast. Scattered spots of higher buoyancy frequency mark the pycnocline, which extends down to $200 \mathrm{~m}$ all along the transect (Figure 8, left panels). The MLD almost coincides with the 28 isopycnal, apart from nearshore where it deepens reaching the 28.25 isopycnal. After the two events of extreme heat loss, the cyclonic eddy dominated the circulation of the NRS. The 
coldest $\left(21.5-22{ }^{\circ} \mathrm{C}\right)$ and saltiest (40.45-40.55) waters were observed around the core of the gyre, which was suggestive of strong vertical mixing arising from the joint effect of upwelling and surface cooling. Remnants of the previous stratification were further disrupted, producing now a more homogenized water column initially at the center of the eddy (Figure 8, mid panels). At the same time, MLD is shallow near the center of the gyre as a result of the doming of the isopycnals induced by the cyclonic circulation. However, it penetrates as deep as the 28.25 isopycnal, while remaining at the 28 isopycnal for the rest of the transect where the disturbance caused by the eddy intensification is still unperceived. Following the recession of the gyre during the middle of February, the water column in the entire section presented the coldest $\left(<22^{\circ} \mathrm{C}\right)$ and saltiest $(>40.5)$ values ever observed throughout the studied period. The disruption of the initial pycnocline gradually propagates to the east and finally a new pycnocline appears again at the top of the water column after the cessation of the cyclonic eddy activity (Figure 7 and 8, right panels). The eastward propagation of the disturbance in the water column following the recession of the cyclonic eddy is also apparent in the MLD which finally settles over the 28.25 pycnocline for the most of the transect. Similar to the first event, warmer $\left(>23^{\circ} \mathrm{C}\right)$ and less saline water $(<40.2)$ is observed at the easternmost part of the glider track, thus limiting the MLD to the 28 isopycnal. This is suggestive of the advent of warmer and fresher water from the south, as also manifested by the geostrophic velocities (Figure 8, bottom right panel). The regional SST variability (Figure 7, lower panels) shows the evolution of the eddy activity and its cooling impact on the eastern half of the NRS. This sequence, from the initially scattered eddies to a main cyclonic gyre and mixing and finally to the advent of water from the south, seem to represent fundamental features that dominate the winter dynamics of the NRS.

\section{Conclusions}

The NRS is an area of fundamental importance for the overturning circulation of the whole Red Sea. Along with the gulfs of Aqaba and Suez, this region fuels the two main, shallow and deep, overturning circulation cells of the Red Sea. Strong atmospheric forcing occurring regularly over the NRS during winter creates the prerequisites for dense water formation. Previous studies, primarily based on numerical simulations, have suggested that over the NRS convection processes produce most of the intermediate water that travels southward and finally exits the basin through the Bab-El-Mandeb strait as the Red Sea Outflow Water (RSOW). Convection processes in the NRS occur during winter under surface cooling and cyclonic eddy activity, which synergistically facilitate the deep mixing. 
First ever consecutive glider deployments on a nearshore-offshore track in the NRS captured the evolution of winter regional dynamics that lead to dense water formation. Atmospheric forcing and eddy activity are both fundamental for the deep mixing process. Under intense cooling events, the transition from a well-stratified to well-mixed water column was facilitated twice by the prevailing of a cyclonic gyre. During the winter of 2015-2016, glider records showed two events involving the activation of the semi-permanent NRS cyclonic gyre. The events were similar in their dynamics, but differed in magnitude. The occurrence of deep convection depends on the persistence of strong atmospheric forcing and on the role of lateral advection that spreads the newly formed dense water at the periphery of the cyclonic gyre. During the first identified event, intermittent atmospheric forcing was incapable to trigger strong convection and lateral advection was still a potent process that helped to maintain the stratification in the surface layer. However, this first event operated as preconditioning to the main second one, during which significant decrease in temperature and a respective increase in salinity were observed in the water column. During the second event, recurrent intense atmospheric forcing episodes induced mixing that penetrated the already weakened upper layer stratification and led to convection and the creation of a dense mixed patch of water. The response of phytoplankton further supported the evidence for deep mixing, and the results also revealed the importance of these events in supplying nutrients to the otherwise oligotrophic NRS ecosystem.

These episodic events leading to a particular mode of dense water formation in the NRS are in agreement with the typical open ocean convection phases as described in Marshall \& Schott (1999). Each episode consists of the following three distinct phases: a) intensification of the cyclonic circulation; b) strong mixing and creation of a deep mixed patch; and c) recession of the gyre and spreading of the mixed patch to its neutrally buoyant levels and advent of warmer and fresher water along the eastern coastline. Although the glider observations collected during the winter of 2015-2016 revealed in detail a process that led to RSOW formation, additional modes of formation likely include shelf dense water formation and feeding from the dense waters of the adjacent gulfs of Aqaba and Suez. Future studies, based on joint observations and model simulations will be needed to examine the robustness of the mechanism proposed on interannual time scales, its relation to other formation sources and its relative contribution to the intermediate waters of the Red Sea. 


\section{Acknowledgments, Samples, and Data}

This work was funded by the Saudi ARAMCO-KAUST Marine Environmental Observatory (SAKMEO) and the KAUST Office of Sponsored Research (OSR) under the Collaborative Research Grant (CRG) program (Grant \# URF/1/2979-01-01). The authors would like to thank Dr. Hari Dasari for providing the atmospheric forcing, and Dr. Nikolaos Zarokanellos and Michel Campbell for valuable advices on various technical issues with the gliders. The authors are also grateful for the NASA Jet Propulsion Laboratory Our Ocean group for providing the G1SST dataset. All data reported in this research will be made fully accessible online. The data supporting the analysis presented in this study are available at Figshare (https://figshare.com/articles/Profiles_Onshore_Offshore/12046209),

DOI:10.6084/m9.figshare.12046209.

\section{References}

Abualnaja, Y., Papadopoulos, V. P., Josey, S. a, Hoteit, I., Kontoyiannis, H., \& Raitsos, D. E. (2015). Impacts of Climate Modes on Air-Sea Heat Exchange in the Red Sea. Journal of Climate, 28(7), 2665-2681. https://doi.org/10.1175/JCLI-D-14-00379.1

Bower, A. S., \& Farrar, J. T. (2015). Air-Sea Interaction and Horizontal Circulation in the Red Sea. In N. M. A. Rasul \& I. C. F. Stewart (Eds.) (Vol. 1900, pp. 329-342). Berlin, Heidelberg: Springer Berlin Heidelberg. https://doi.org/10.1007/978-3-662-45201-1_19

de Boyer Montégut, C., Madec, G., Fischer, A. S., Lazar, A., \& Iudicone, D. (2004). Mixed layer depth over the global ocean: An examination of profile data and a profile-based climatology. Journal of Geophysical Research C: Oceans, 109(12), 1-20. https://doi.org/10.1029/2004JC002378

Cember, R. P. (1988). On the sources, formation, and circulation of Red Sea deep water. Journal of Geophysical Research, 93(C7), 8175. https://doi.org/10.1029/JC093iC07p08175

Chao, Y., Li, Z., Farrara, J. D., \& Hung, P. (2009). Blending sea surface temperatures from multiple satellites and in situ observations for coastal oceans. Journal of Atmospheric and Oceanic Technology, 26(7), 1415-1426. https://doi.org/10.1175/2009JTECHO592.1

Dasari, H. P., Langodan, S., Viswanadhapalli, Y., Vadlamudi, B. R., Papadopoulos, V. P., \& Hoteit, I. (2017). ENSO influence on the interannual variability of the Red Sea convergence zone and associated rainfall. International Journal of Climatology. 
https://doi.org/10.1002/joc.5208

Dasari, H. P., Desamsetti, S., Langodan, S., Attada, R., Kunchala, R. K., Viswanadhapalli, Y., et al. (2019). High-resolution assessment of solar energy resources over the Arabian Peninsula. Applied Energy, 248, 354-371.

https://doi.org/10.1016/j.apenergy.2019.04.105

Eshel, G., Cane, M. A., \& Blumenthal, M. B. (1994). Modes of subsurface, intermediate, and deep water renewal in the Red Sea. Journal of Geophysical Research, 99(C8), 1594115952. https://doi.org/10.1029/94JC01131

Genin, A., Lazar, B., \& Brenner, S. (1995). Vertical mixing and coral death in the red sea following the eruption of Mount Pinatubo. Nature, 377(6549), 507-510. https://doi.org/10.1038/377507a0

Gittings, J. A., Raitsos, D. E., Krokos, G., \& Hoteit, I. (2018). Impacts of warming on phytoplankton abundance and phenology in a typical tropical marine ecosystem. Scientific Reports, 8(1). https://doi.org/10.1038/s41598-018-20560-5

Gittings, J. A., Raitsos, D. E., Kheireddine, M., Racault, M. F., Claustre, H., \& Hoteit, I. (2019). Evaluating tropical phytoplankton phenology metrics using contemporary tools. Scientific Reports, 9(1), 1-10. https://doi.org/10.1038/s41598-018-37370-4

Kim, K., Chang, K. Il, Kang, D. J., Kim, Y. H., \& Lee, J. H. (2008). Review of recent findings on the water masses and circulation in the East Sea (Sea of Japan). Journal of Oceanography, 64(5), 721-735. https://doi.org/10.1007/s10872-008-0061-x

Langodan, S., Cavaleri, L., Viswanadhapalli, Y., \& Hoteit, I. (2014). The Red Sea: A Natural Laboratory for Wind and Wave Modeling. Journal of Physical Oceanography, 44(12), 3139-3159. https://doi.org/10.1175/JPO-D-13-0242.1

Langodan, S., Cavaleri, L., Viswanadhapalli, Y., \& Hoteit, I. (2015). Wind-wave source functions in opposing seas. Journal of Geophysical Research: Oceans, 120(10), 67516768. https://doi.org/10.1002/2015JC010816

Langodan, S., Viswanadhapalli, Y., Dasari, H. P., Knio, O., \& Hoteit, I. (2016). A highresolution assessment of wind and wave energy potentials in the Red Sea. Applied Energy, 181, 244-255. https://doi.org/10.1016/j.apenergy.2016.08.076

Langodan, S., Cavaleri, L., Vishwanadhapalli, Y., Pomaro, A., Bertotti, L., Hoteit, I., et al. (2017). The climatology of the Red Sea - part 2: The waves. International Journal of Climatology. https://doi.org/10.1002/joc.5101

Malanotte-Rizzoli, P., Artale, V., Borzelli-Eusebi, G. L., Brenner, S., Crise, A., Gacic, M., et al. (2014). Physical forcing and physical/biochemical variability of the Mediterranean 
Sea: A review of unresolved issues and directions for future research. Ocean Science, 10(3), 281-322. https://doi.org/10.5194/os-10-281-2014

Marshall, J., \& Schott, F. (1999). Open-ocean convection: Observations, theory, and models. Reviews of Geophysics, 37(1), 1-64. https://doi.org/10.1029/98RG02739

Menezes, V., Farrar, T., \& Bower, A. (2019). Evaporative Implications of Dry-Air Outbreaks Over the Northern Red Sea. Journal of Geophysical Research : Atmospheres, 124(9), 4829-4861. https://doi.org/10.1029/2018JD028853

Organelli, E. (2017). Bio-optical anomalies in the world's oceans: An investigation. Journal of Geophysical Research : Oceans, 3543-3564. https://doi.org/10.1002/2016JC012629

Osipov, S., \& Stenchikov, G. (2017). Regional Effects of the Mount Pinatubo Eruption on the Middle East and the Red Sea. Journal of Geophysical Research: Oceans, 122(11), 8894-8912. https://doi.org/10.1002/2017JC013182

Papadopoulos, V. P., Abualnaja, Y., Josey, S. a., Bower, A. S., Raitsos, D. E., Kontoyiannis, H., \& Hoteit, I. (2013). Atmospheric Forcing of the Winter Air-Sea Heat Fluxes over the Northern Red Sea. Journal of Climate, 26(5), 1685-1701. https://doi.org/10.1175/JCLI-D-12-00267.1

Papadopoulos, V. P., Zhan, P., Sofianos, S., Raitsos, D. E., Qurban, M., Abualnaja, Y., et al. (2015). Factors governing the deep ventilation of the Red Sea. Journal of Geophysical Research: Oceans, 120(11), 7493-7505. https://doi.org/10.1002/2015JC010996

Roesler, C., Uitz, J., Claustre, H., Boss, E., Xing, X., Organelli, E., et al. (2017).

Recommendations for obtaining unbiased chlorophyll estimates from in situ chlorophyll fluorometers: A global analysis of WET Labs ECO sensors. Limnology and Oceanography: Methods, 15(6), 572-585. https://doi.org/10.1002/lom3.10185

Schmechtig, C., Thierry, V., \& The Bio-Argo Team. (2016). Argo Quality Control Manual for Biogeochemical Data. Argo Data Management, (March), 1-54. https://doi.org/10.13155/40879

Sofianos, S., \& Johns, W. E. (2003). An Oceanic General Circulation Model (OGCM) investigation of the Red Sea circulation: 2. Three-dimensional circulation in the Red Sea. Journal of Geophysical Research, 108(C3), 3066. https://doi.org/10.1029/2001JC001185

Sofianos, S., \& Johns, W. E. (2007). Observations of the summer Red Sea circulation. Journal of Geophysical Research, 112(6), 1-20. https://doi.org/10.1029/2006JC003886 Sofianos, S., \& Johns, W. E. (2015). The Red Sea: Water Mass Formation, Overturning Circulation, and the Exchange of the Red Sea with the Adjacent Basins. (N. M. A. Rasul 
\& I. C. F. Stewart, Eds.). Berlin, Heidelberg: Springer Berlin Heidelberg. https://doi.org/10.1007/978-3-662-45201-1

Sofianos, S., Johns, W. E., \& Murray, S. P. (2002). Heat and freshwater budgets in the Red Sea from direct observations at Bab el Mandeb. Deep-Sea Research Part II: Topical Studies in Oceanography, 49, 1323-1340. https://doi.org/10.1016/S09670645(01)00164-3

Sparnocchia, S., Picco, P., Manzella, G. M. R., Ribotti, A., Copello, S., \& Brasey, P. (1995). Intermediate water formation in the Ligurian Sea. Oceanologica Acta, 18(2), 151-162. Takeshita, Y., Martz, T. R., Coletti, L. J., Dickson, A. G., Jannasch, H. W., \& Johnson, K. S. (2017). The effects of pressure on $\mathrm{pH}$ of Tris buffer in synthetic seawater. Marine Chemistry, 188, 1-5. https://doi.org/10.1016/j.marchem.2016.11.002

Thierry, V., Gilbert, D., \& Kobayashi, T. (2011). Processing Argo OXYGEN data at the DAC level. AST-10 Meeting, 1-12.

Viswanadhapalli, Y., Dasari, H. P., Langodan, S., Challa, V. S., \& Hoteit, I. (2016). Climatic features of the Red Sea from a regional assimilative model. International Journal of Climatology. https://doi.org/10.1002/joc.4865

Woelk, S., \& Quadfasel, D. (1996). Renewal of deep water in the Red Sea during 1982-1987. Journal of Geophysical Research, 101, 18155-18165. https://doi.org/10.1029/96jc01148

Wong, A., Keeley, R., \& Carval, T. (2018). Argo Quality Control Manual For CTD and Trajectory Data, (February), 1-58. https://doi.org/10.13155/33951

Xing, X., Morel, A., Claustre, H., D’Ortenzio, F., \& Poteau, A. (2012). Combined processing and mutual interpretation of radiometry and fluorometry from autonomous profiling Bio-Argo floats: 2. Colored dissolved organic matter absorption retrieval. Journal of Geophysical Research: Oceans, 117(4). https://doi.org/10.1029/2011JC007632

Yao, F., \& Hoteit, I. (2018). Rapid red sea deep water renewals caused by volcanic eruptions and the north atlantic oscillation. Science Advances, 4(6), 1-10. https://doi.org/10.1126/sciadv.aar5637

Yao, F., Hoteit, I., Pratt, L. J., Bower, A. S., Zhai, P., Köhl, A., \& Gopalakrishnan, G. (2014). Seasonal overturning circulation in the Red Sea: 1 . Model validation and summer circulation. Journal of Geophysical Research: Oceans, 119, 2238-2262. https://doi.org/10.1002/2013JC009004

Yao, F., Hoteit, I., Pratt, L. J., Bower, A. S., Köhl, A., Gopalakrishnan, G., \& Rivas, D. (2014a). Seasonal overturning circulation in the Red Sea: 2. Winter circulation. Journal of Geophysical Research: Oceans, 119(4), 2263-2289. 
https://doi.org/10.1002/2013JC009331

Yao, F., Hoteit, I., Pratt, L. J., Bower, A. S., Köhl, A., Gopalakrishnan, G., \& Rivas, D. (2014b). Seasonal overturning circulation in the Red Sea: 2. Winter circulation. Journal of Geophysical Research: Oceans, 119(4), 2263-2289. https://doi.org/10.1002/2013JC009331

Zhai, P., Bower, A. S., Smethie, W. M., \& Pratt, L. J. (2015). Formation and spreading of Red Sea Outflow Water in the Red Sea. Journal of Geophysical Research: Oceans, 120(9), 6542-6563. https://doi.org/10.1002/2015JC010751

Zhan, P., Subramanian, A. C., Yao, F., \& Hoteit, I. (2014). Eddies in the Red Sea: A statistical and dynamical study. Journal of Geophysical Research: Oceans, 119(6), 3909-3925. https://doi.org/10.1002/2013JC009563

Zhan, P., Subramanian, A. C., Yao, F., Kartadikaria, A. R., Guo, D., \& Hoteit, I. (2016). The eddy kinetic energy budget in the Red Sea. Journal of Geophysical Research: Oceans, 121(7), 4732-4747. https://doi.org/10.1002/2015JC011589

Zhan, P., Gopalakrishnan, G., Subramanian, A. C., Guo, D., \& Hoteit, I. (2018). Sensitivity Studies of the Red Sea Eddies Using Adjoint Method. Journal of Geophysical Research: Oceans, 123(11), 8329-8345. https://doi.org/10.1029/2018JC014531 


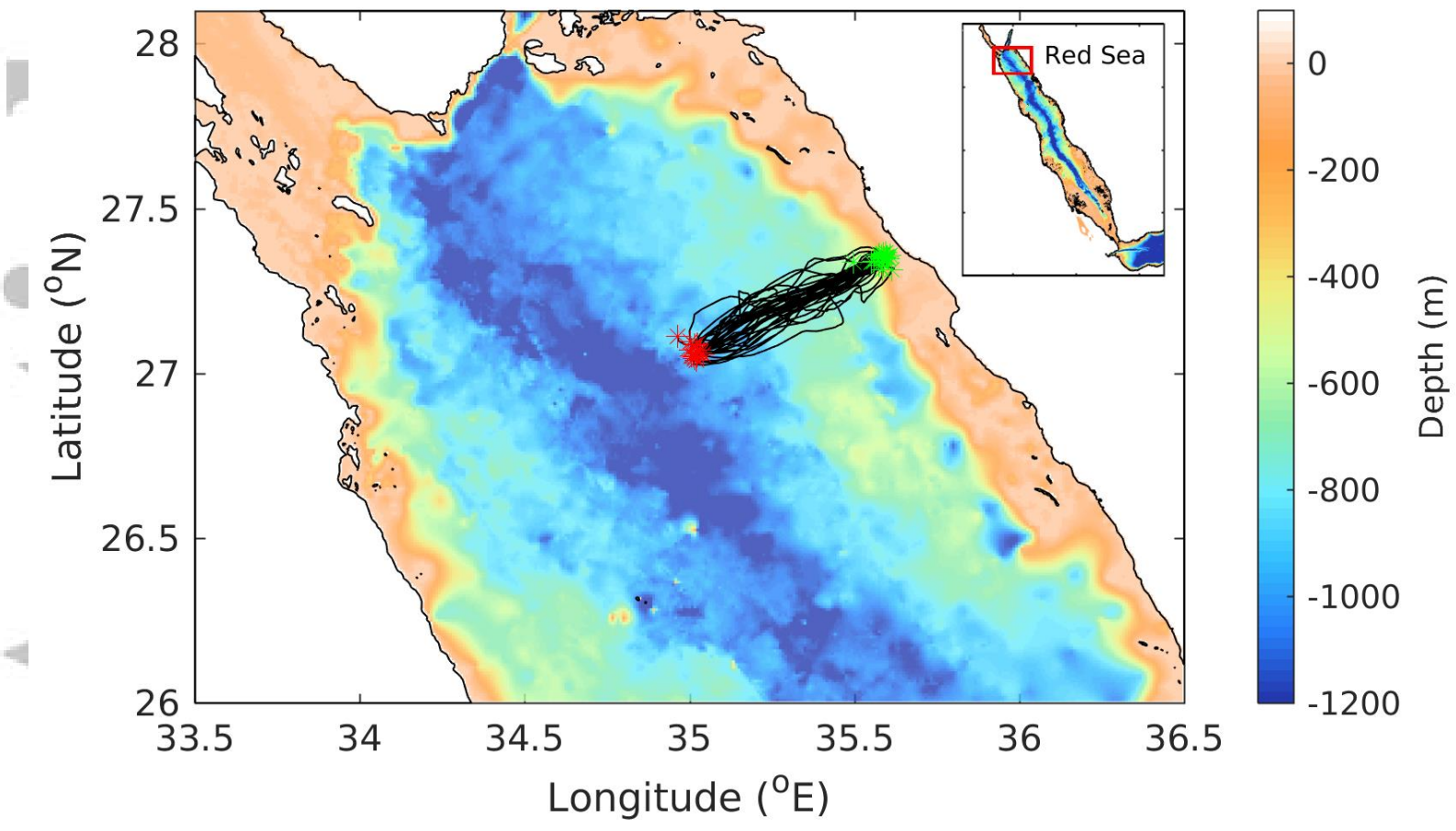

Figure 1. The northern Red Sea (NRS) and the actual glider tracks. The green and red dots indicate the intended inshore and offshore waypoints, respectively. 

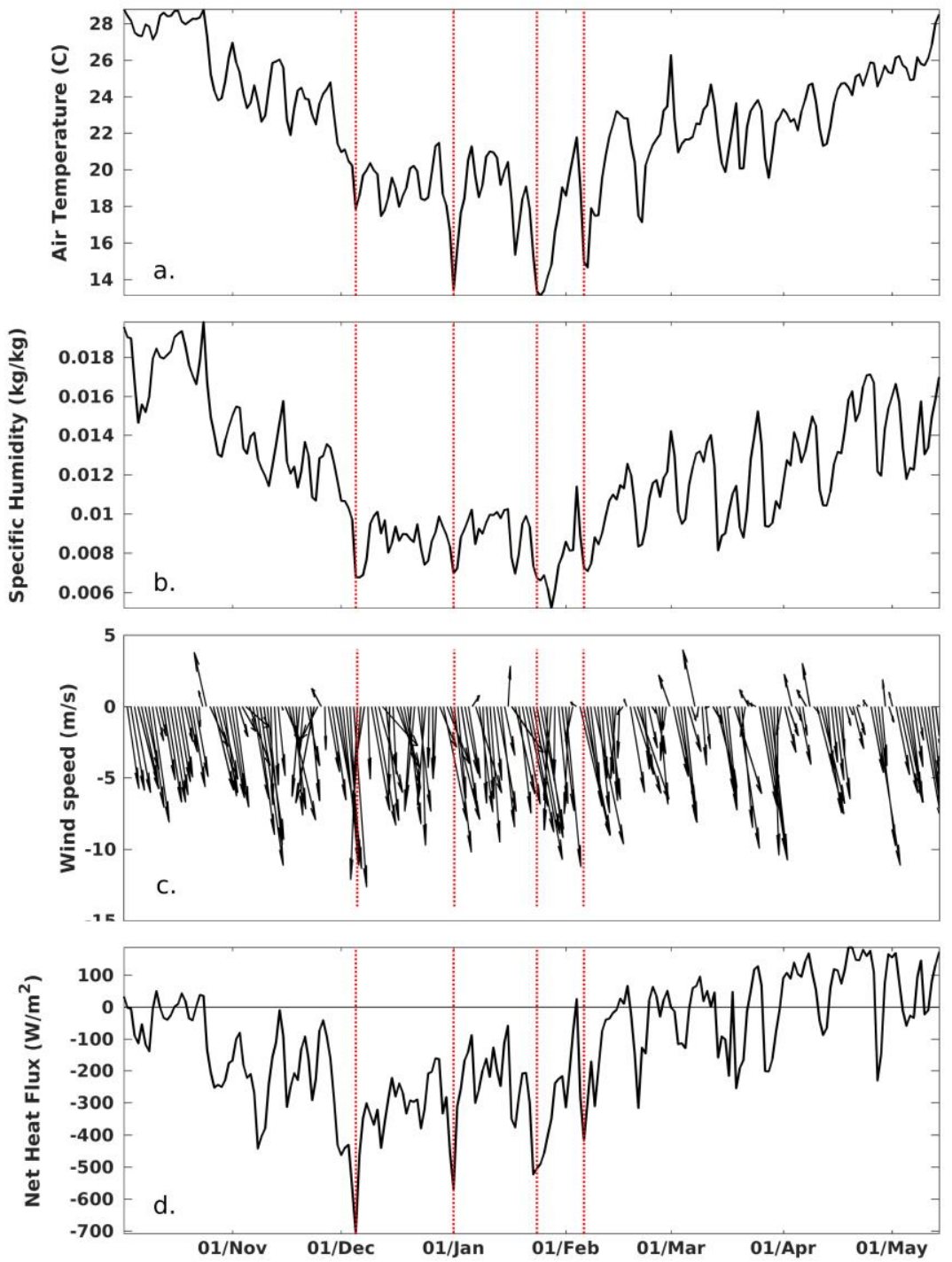

Figure 2. Evolution of the air temperature (a), specific humidity (b), wind velocity (c), and net heat flux (d) during the glider observation period as derived from the high resolution downscaled model simulation. Red vertical lines mark episodes of the highest heat loss. 


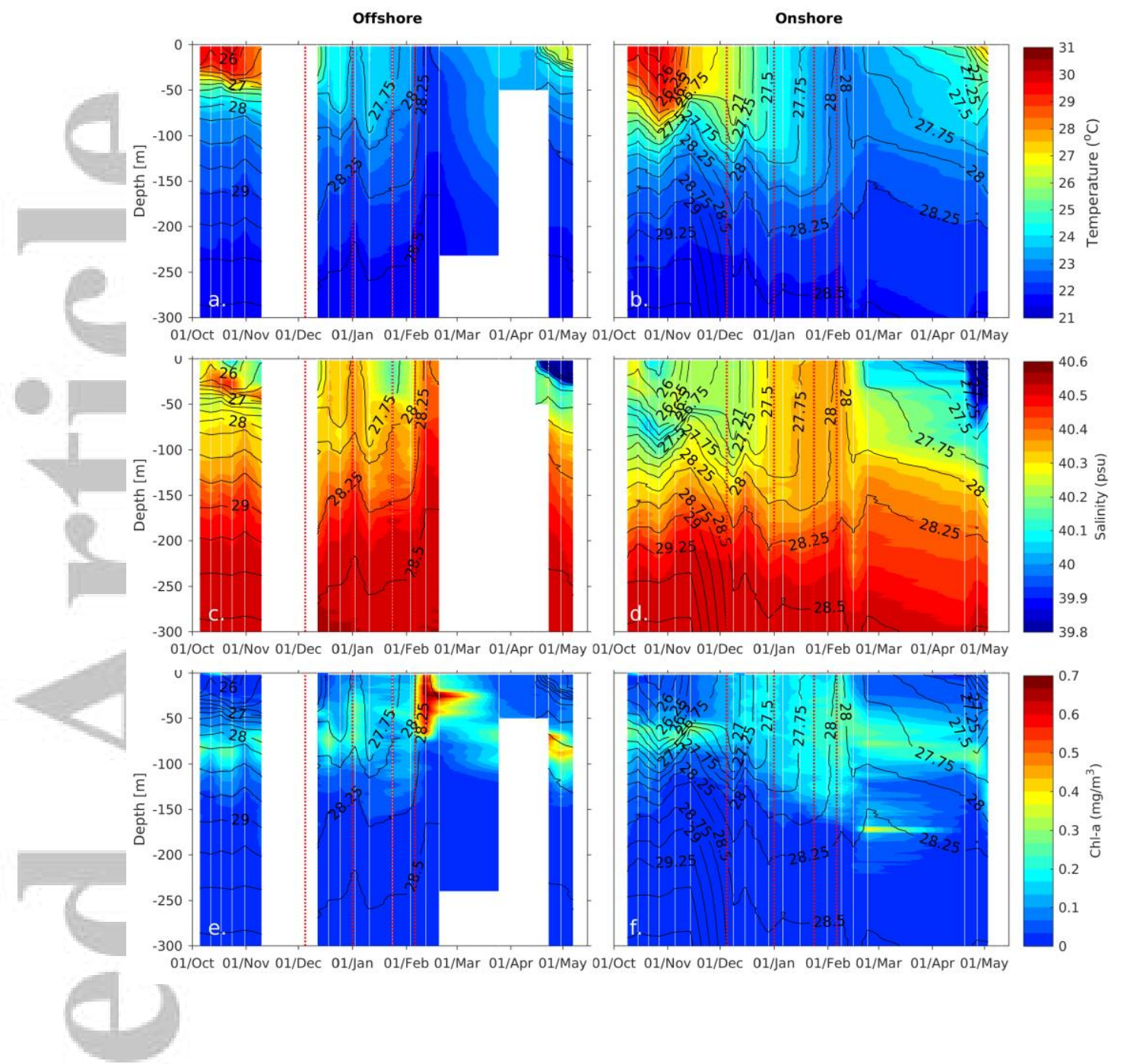

Figure 3. Temporal variation of temperature (a, b), salinity $(c, d)$, and chlorophyll (e, f) at the offshore and nearshore ends of the glider track. Contour lines denote potential density $(\mathrm{Kg} / \mathrm{m} 3)$. White lines correspond to the profile sampling and red vertical lines to the episodes of highest heat loss. 

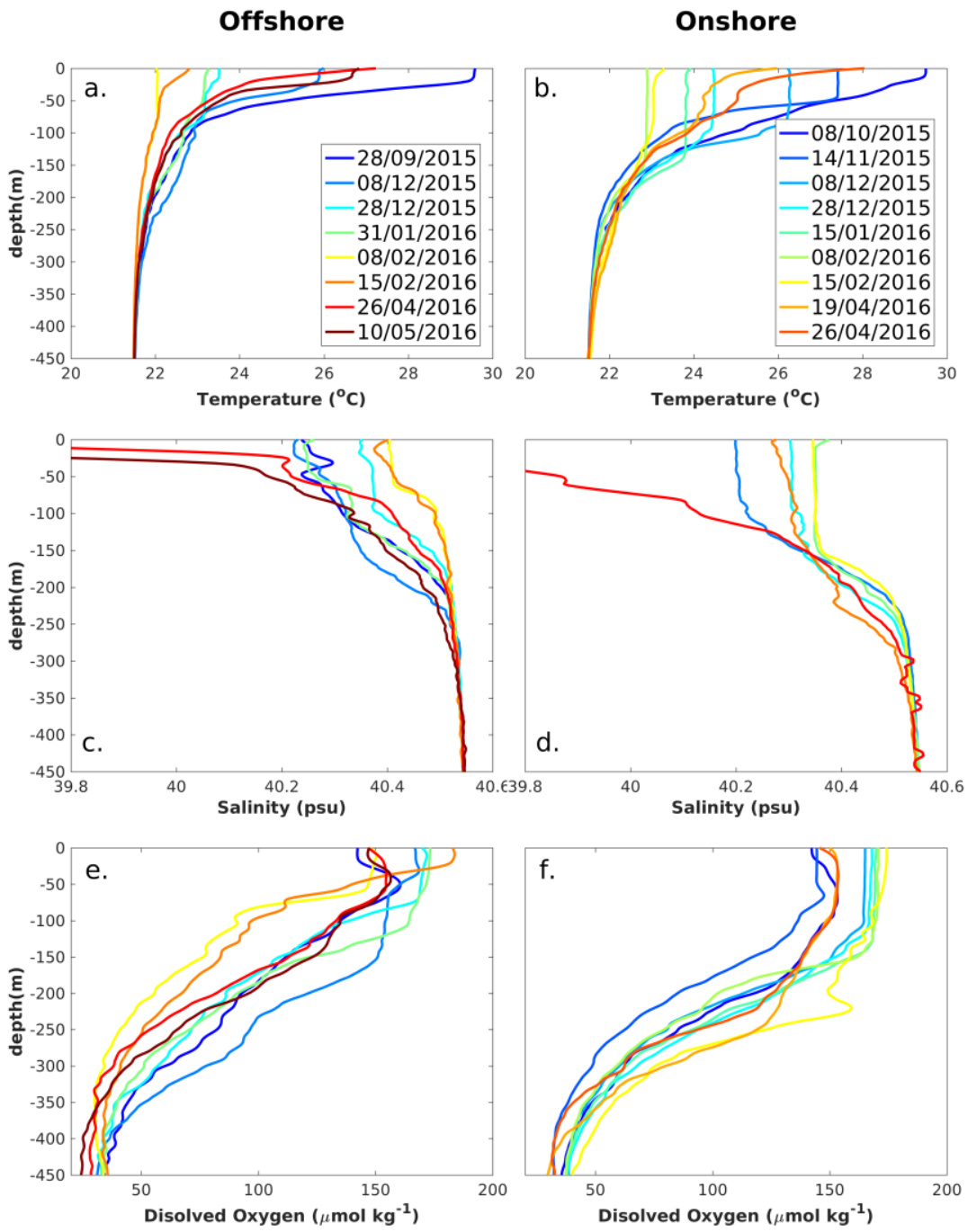

Figure 4. Selected offshore and onshore vertical profiles for temperature, salinity, and dissolved oxygen concentration during the glider deployment period. 


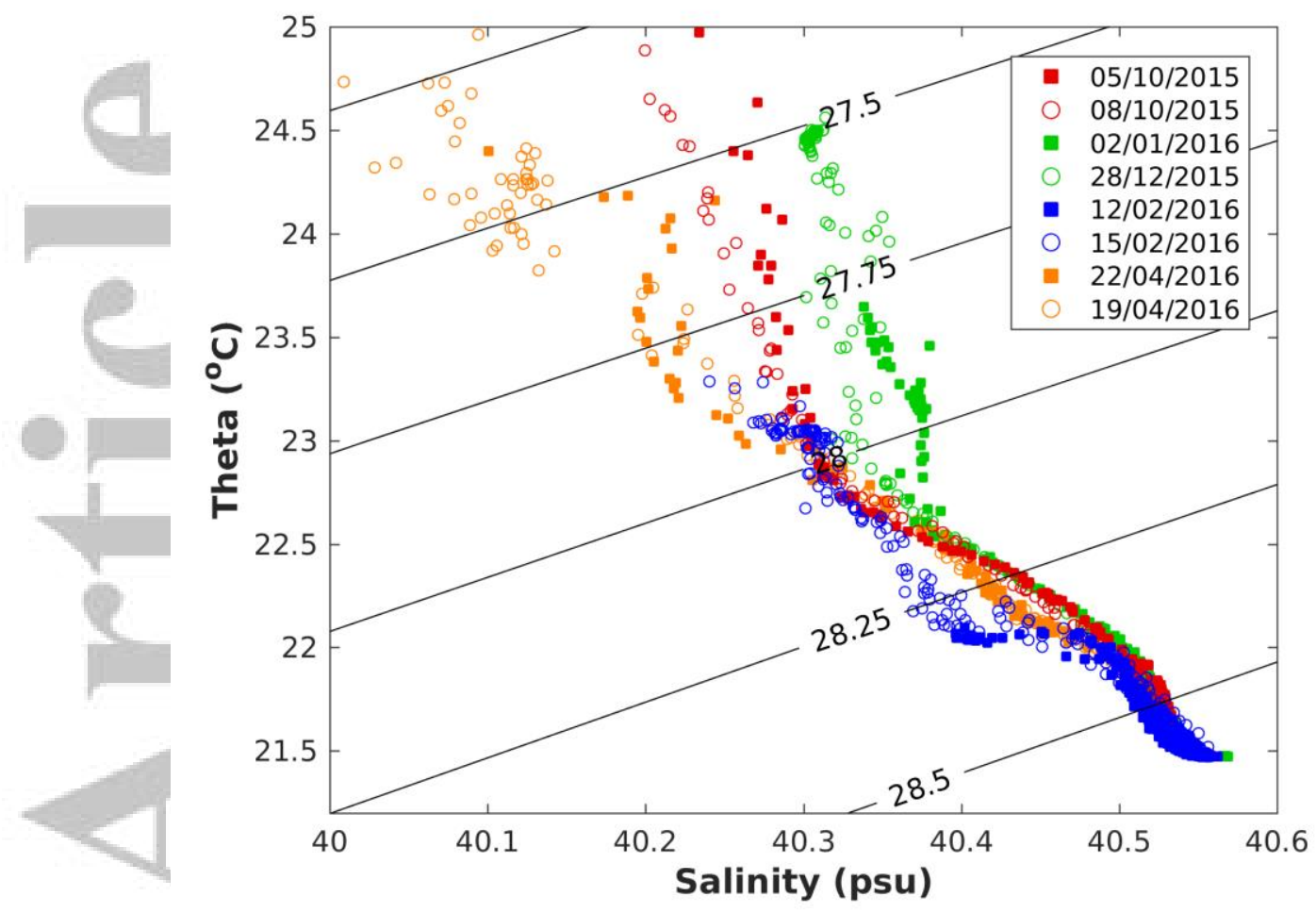

Figure 5. T-S diagram displaying the evolution of the water masses at the onshore (circles) and offshore (squares) locations of the glider tracks. 

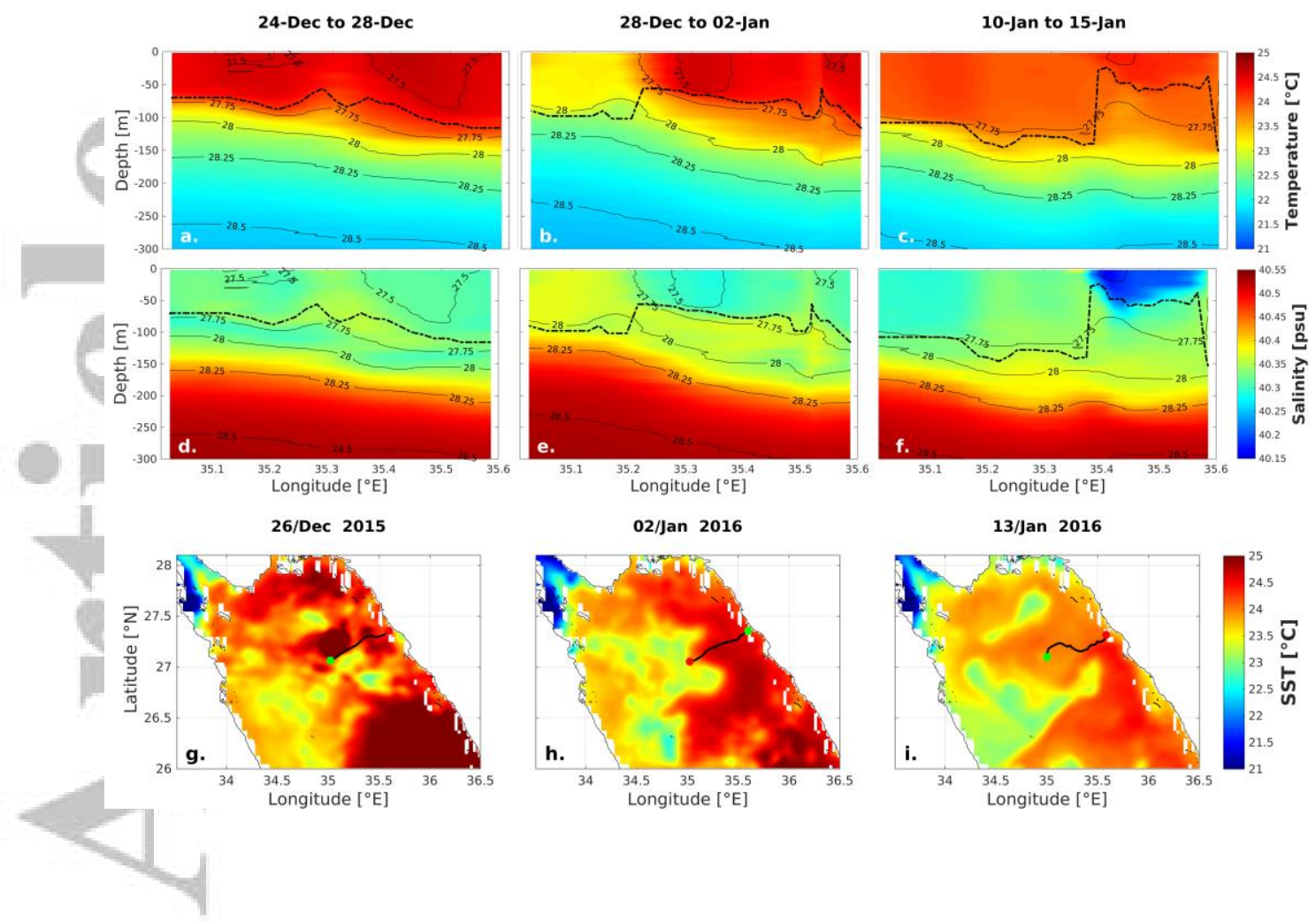

Figure 6. Glider transects during the first appearance of the cyclonic gyre in the NRS and representative regional SST during each period. Black contour lines represent the isopycnals and the thick dashed black lines represent the mixed layer depth in the top and mid panels. Green and red dots at the edges of the glider tracks (blacklines) in the bottom panel denote the starting and ending points, respectively. 

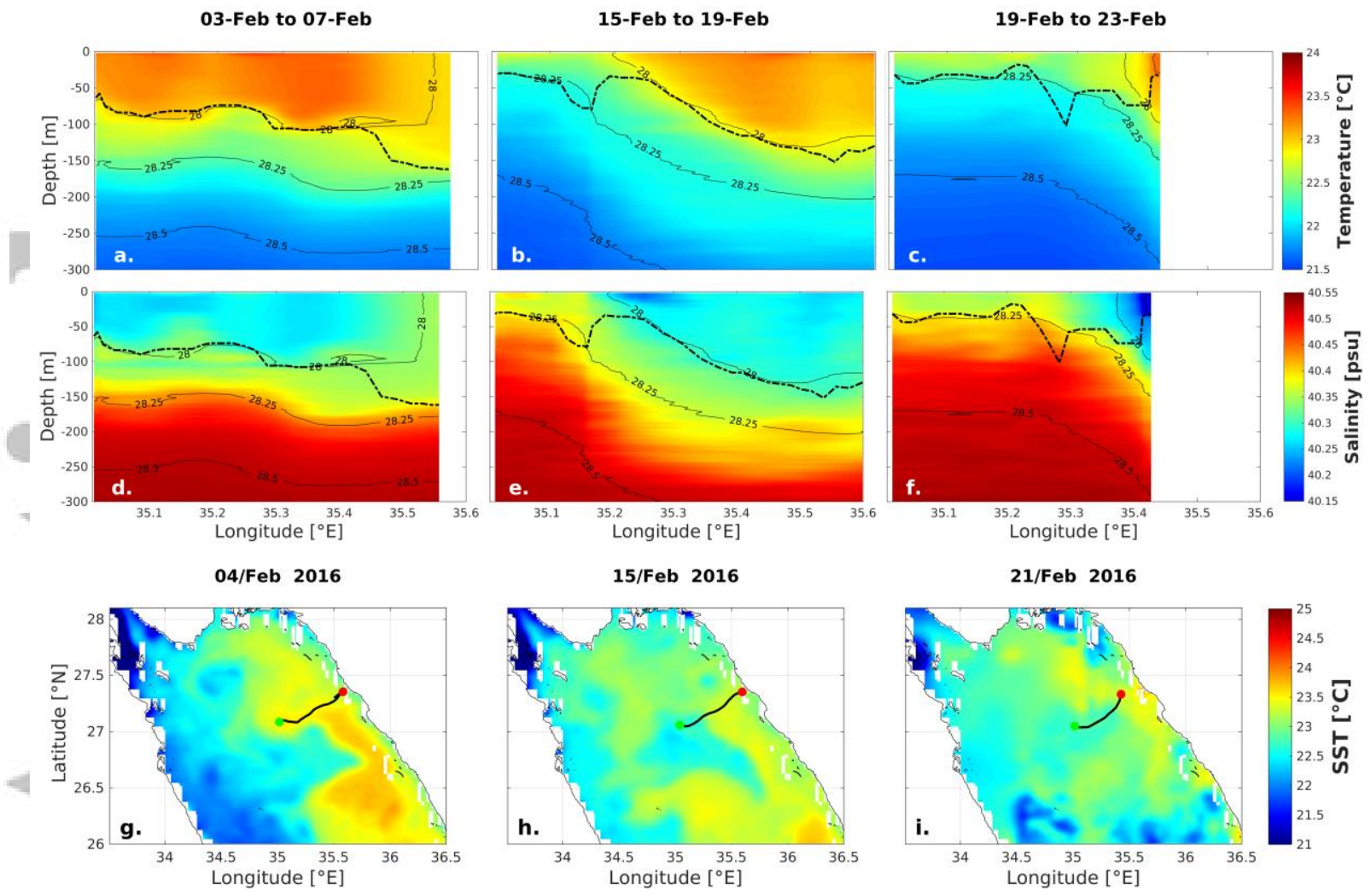

Figure 7. As in Figure 5, but for the second appearance of the cyclonic gyre. 


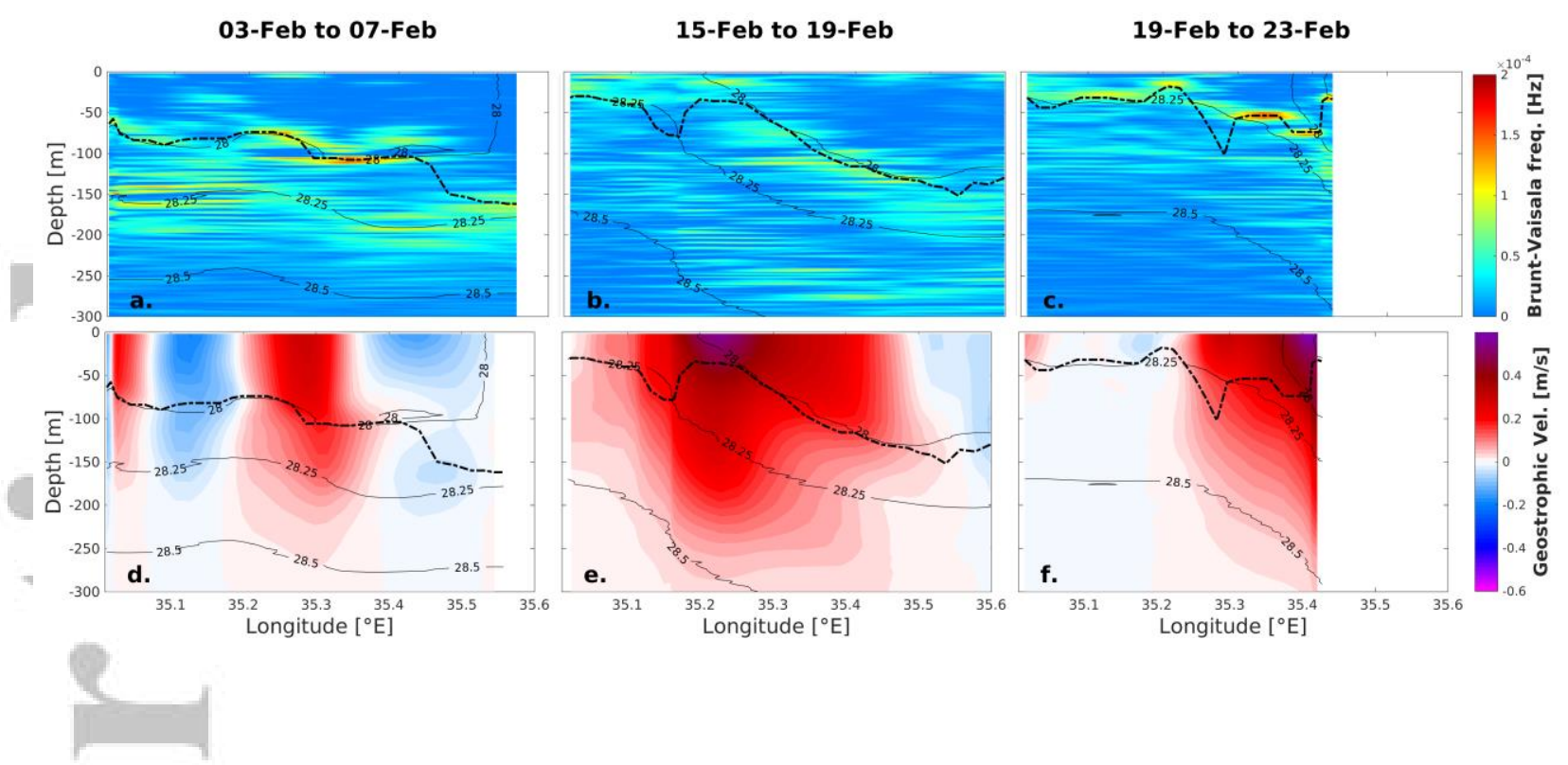

Figure 8. Brunt-Vaisala frequency and geostrophic velocity as derived by the glider transects during the second appearance of the cyclonic gyre in the NRS. Positive geostrophic velocity refers to a northward flow. The thick dashed black line shows the mixed layer depth.

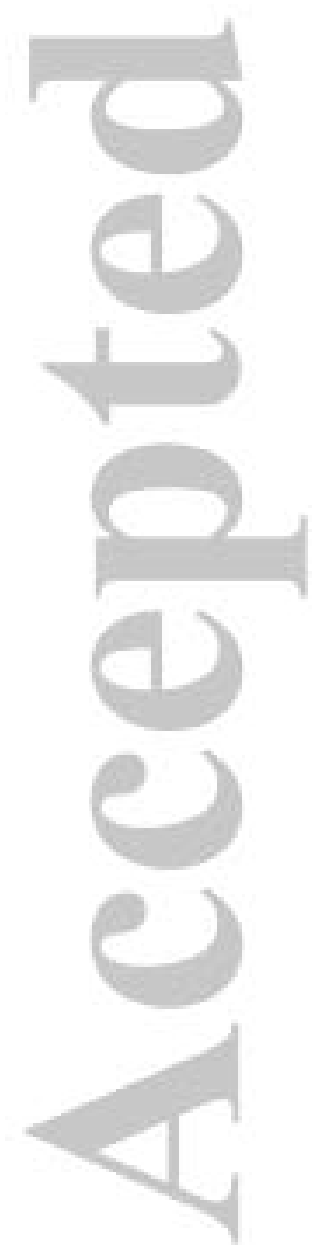


Table 1: Details of the seaglider missions (Useful days represent the data acquisition period)

\begin{tabular}{|c|c|c|c|c|}
\hline Glider ID & Launching Date & Recovery Date & $\begin{array}{c}\text { Useful } \\
\text { Days }\end{array}$ & $\begin{array}{c}\text { Total } \\
\text { Days }\end{array}$ \\
\hline SG213 & Sep 28,2015 & Dec 1,2015 (14 Nov) & 47 & 65 \\
\hline SG214 & Dec 2,2015 & Mar 25,2016 (8 Mar) & 98 & 115 \\
\hline SG212 & Apr 6,2016 & May 09,2016 & 34 & 34 \\
\hline
\end{tabular}

